\title{
Effect of Harvest Year and Altitude on Nutritional and Biometric Characteristics of Blueberry Cultivars
}

\author{
Sofia Correia, ${ }^{1}$ Berta Gonçalves, ${ }^{1,2}$ Alfredo Aires, ${ }^{1}$ Ademar Silva, ${ }^{3}$ \\ Luís Ferreira, ${ }^{4}$ Rosa Carvalho, ${ }^{3}$ Hortense Fernandes, ${ }^{3}$ Cândida Freitas, ${ }^{5}$ \\ Valdemar Carnide, ${ }^{6}$ and Ana Paula Silva ${ }^{1,3}$ \\ ${ }^{1}$ Centre for the Research and Technology of Agro-Environmental and Biological Sciences (CITAB), \\ University of Trás-os-Montes e Alto Douro, Quinta de Prados, 5000-801 Vila Real, Portugal \\ ${ }^{2}$ Department of Biology and Environment, University of Trás-os-Montes e Alto Douro, Quinta de Prados, \\ 5000-801 Vila Real, Portugal \\ ${ }^{3}$ Department of Agronomy, University of Trás-os-Montes e Alto Douro, Quinta de Prados, 5000-801 Vila Real, Portugal \\ ${ }^{4}$ Department of Zootechny, Veterinary and Animal Science Research Center (CECAV), \\ University of Trás-os-Montes e Alto Douro, Quinta de Prados, 5000-801 Vila Real, Portugal \\ ${ }^{5}$ Mirtilusa-Sociedade de Produtores Horto-Frutícolas, Lda. Rua da Meia Encosta, 3740-233 Sever do Vouga, Portugal \\ ${ }^{6}$ Department of Genetics and Biotechnology, Center of Genomics and Biotechnology (CGB), \\ University of Trás-os-Montes e Alto Douro, Quinta de Prados, 5000-801 Vila Real, Portugal \\ Correspondence should be addressed to Sofia Correia; sofiacorreia@utad.pt
}

Received 5 January 2016; Revised 14 March 2016; Accepted 3 April 2016

Academic Editor: Jorge Barros-Velázquez

Copyright (c) 2016 Sofia Correia et al. This is an open access article distributed under the Creative Commons Attribution License, which permits unrestricted use, distribution, and reproduction in any medium, provided the original work is properly cited.

In recent years the consumption of small fruits has increased continuously and knowledge about the more suitable production requirements is essential. This study aims to evaluate the influence of harvest year and altitude on chemical composition of four blueberry cultivars, in order to create rentable opportunities for producers and minimize eventual losses in quality fruits. Dry mass, protein, fat, energy, free sugars, organic acids, and vitamin C contents were determined using HPLC-UV-DAD and spectrophotometric methods. Differences $(p<0.05)$ in the concentrations of free sugars, organic acids, and vitamin $\mathrm{C}$ were found among years, while the altitude had no $(p>0.05)$ influence. Citric acid was the main organic acid and fructose the most abundant sugar in blueberries. Fruits of "Ozarkblue" had the highest mass and volume whilst the "Bluecrop" was the cultivar with highest crude protein and fat contents. "Goldtraube" showed the highest content of sucrose and organic acids and "Duke" had the highest content of fructose.

\section{Introduction}

Highbush blueberries (Vaccinium corymbosum L.) are originated from North America and are cultivated for many years in USA [1]. The area dedicated to this crop in Europe has increased particularly in countries such as Italy, France, Germany, and Netherlands and the greatest growth in the last five years has been in Poland, Spain, and Portugal [2]. The actual tendency in the world is permanent increasing of production of small fruits, such as blueberries.
Consumer interest in food composition has intensified as it allows them to choose fruits and vegetables with greater nutrient contents, particularly those related to beneficial biological properties such as antiaging, anti-inflammatory, antioxidant, and anticancer [3,4]. Berry fruits have been gradually recognized as a rich source of bioactive compounds also known as phytochemicals, including phenolics, vitamin C, free sugars, and organic acids [3, 4]. Some of these compounds have shown high antioxidant potential, 
particularly phenolics $[5,6]$. Other important compound largely studied in different crops and food matrices is the ascorbic acid (vitamin C). Vitamin C is a bioactive compound which in combination with other compounds is responsible for antioxidant proprieties [7]. Prior et al. [8] indicated that highbush blueberry has high levels of vitamin $\mathrm{C}$ and reported a significant variability between cultivars and species of Vaccinium. The vitamin C content seems to be mainly affected by high light intensity and high temperature before harvest [9]. Thus, the assessment of the influence of biotic and abiotic factors on the chemical composition of blueberries is needed.

The quality attributes of blueberries (and other berries) and their content on nutraceutical substances are dependent on different factors such as cultivar or genotype, growing and environmental conditions, ripening stage, agricultural practices, postharvest conditions, and processing procedures [10]. Several studies have characterized the physical, morphological, and chemical properties of different cultivars of blueberries [11]. Fruit size and ripeness seem to be correlated, but other traits, such as number of seeds, number of fruits per shoot, crop load, and water status, can also affect the fruit size [12]. Fruit weight shows a great variation within cultivars, whilst the fruit firmness seems to be directly related either to the harvest time or to cultivar and season [13]. The berry moisture content as well as its dry mass is significantly influenced by growing environmental conditions as reported by Starast et al. [14]. The ripeness stage seems to be fundamental for the fruit quality. Changes in organic acids and sugars' contents during ripeness process are important factors in flavor development and sensory characteristics of fruits [15-17]. They are the main soluble constituents of strawberry, sweet cherry, and mulberry fruits and organoleptic assessment is greatly influenced by their contents $[18,19]$. One important characteristic in highbush blueberries is its colour that is dependent on the accumulation of anthocyanins, $\mathrm{pH}$, and maturity stage [20]. In general, the dominant individual sugar of blueberry fruits is fructose, followed by glucose and sucrose [12]. The predominant organic acid is usually citric acid followed by small concentrations of succinic, quinic, and malic acids [21].

The nutritional composition and content of bioactive compounds in blueberries vary widely with the cultivar, season, and growing location. Several studies have been dedicated to the study of phenolics variation with year and cultivar $[8,22,23]$, but the effect of altitude and climate conditions throughout the years on the nutritional quality of blueberries has been scarcely studied. The study of climatic variations associated with geographic conditions in blueberry production is important to understand the differences that occurred in their quality and to decide how to optimize the ripeness stage, which is an essential key factor for the fruits quality. Therefore, the aim of the present study was to evaluate the nutritional and chemical composition of four highbush blueberry (Vaccinium corymbosum L.) cultivars recently introduced in Portugal, namely, "Duke," "Bluecrop," "Goldtraube," and "Ozarkblue." Cultivars were harvested in three consecutive years at two different altitudes to evaluate the impact of the year and, consequently, the climate and the altitude on free sugars, organic acids, and vitamin $\mathrm{C}$ of blueberries produced in Central Portugal.

\section{Materials and Methods}

2.1. Sample Collection. The northern highbush blueberry cultivars ("Duke," "Bluecrop," "Goldtraube," and "Ozarkblue") were harvested in Sever do Vouga region $\left(40^{\circ} 44^{\prime} 0^{\prime \prime} \mathrm{N}, 8^{\circ}\right.$ $22^{\prime} 9^{\prime \prime} \mathrm{W}$ ) at two different altitudes: up to 217 meters (considered low altitude) and up to 636 meters (considered high altitude). Blueberries bush cultivars were planted between 2000 and 2003. Plant spacing was $1.5 \mathrm{~m}$ within the rows and $2.0 \mathrm{~m}$ between rows. The irrigation regime was performed dropwise. Blueberries were harvested from the middle of May to the end of July in three consecutive years (20112013). The harvesting dates are listed in Supporting Information Table 1 (see Supplementary Material available online at http://dx.doi.org/10.1155/2016/8648609). Fruits were selected at commercial maturity stage, based on their color, flavor, and texture. From each altitude and at the same stage of ripeness $1 \mathrm{~kg}$ of fruits per cultivar was collected. Immediately after harvest, fruits were transferred to laboratory to start the analytic procedure, including biometric measurements, mass, and volume. Blueberries were then divided into $100 \mathrm{~g}$ portions into plastic food bags, sealed, and stored at $-20^{\circ} \mathrm{C}$ until further chemical analysis.

2.2. Climate Conditions. Data on weather conditions were provided by the National Information System for Hydric Resources (SNIRH) and Portuguese Institute of the Sea and the Atmosphere (IPMA). Data were recorded at weather stations of these institutes, near the experimental fields, during the 3 years of experiments. Weather parameters (i.e., temperature and precipitation) in the years 2011, 2012, and 2013 are presented in Table 1. The climate is characterized as a transition from Csb to Csa (mesothermic climate with a partially dry summer) of Köpen.

2.3. Determination of Fresh Mass and Volume, Dry Mass, Crude Protein, Crude Fat, and Energy. For fresh mass determination, 30 fruits of each cultivar were weighed. The volume of these fruits was measured using a beaker with $100 \mathrm{~mL}$ of water. The average blueberry fresh mass (g) and fresh volume $(\mathrm{mL})$ were calculated.

Blueberries of each cultivar $(100 \mathrm{~g})$ were immediately dried on the harvest day, using a forced-air oven at $60^{\circ} \mathrm{C}$ during $72 \mathrm{~h}$, for dry mass (DM) determination. Total nitrogen was determined as Kjeldahl $N$ (number 954.01, AOAC, 1990) using Kjeltec System 1026 Distillation Unit. Crude protein (CP) was calculated as Kjeldahl $N \times 6.25$. The crude fat $(\mathrm{CF})$ was extracted using the organic solvent (petroleum ether) according to the procedures of the Soxtec System HT equipment. The energy content of the samples was determined using an adiabatic oxygen bomb calorimeter (Parr 6300, Moline, IL, USA). DM was expressed as percentage (\%) and $\mathrm{CP}$ and $\mathrm{CF}$ were expressed as $\mathrm{g} \cdot 100 \mathrm{~g}^{-1} \mathrm{DM}$. Energy content 
TABLE 1: Monthly acquired meteorological data in the growing season from March to July for Sever do Vouga in the period 201113.

\begin{tabular}{|c|c|c|c|c|c|c|}
\hline Year & Month & $\begin{array}{l}T_{\mathrm{m}} \\
\left({ }^{\circ} \mathrm{C}\right)\end{array}$ & $\begin{array}{l}\text { TOD } \\
\left({ }^{\circ} \mathrm{C}\right)\end{array}$ & $\begin{array}{c}\text { Ppt } \\
(\mathrm{mm})\end{array}$ & $\begin{array}{l}\mathrm{RP} \\
(\%)\end{array}$ & $\begin{array}{c}\mathrm{RO} \\
\left(\mathrm{MJ} \cdot \mathrm{m}^{-2}\right)\end{array}$ \\
\hline \multirow{5}{*}{2011} & March & 11.2 & 0.2 & 60 & 75 & 500 \\
\hline & April & 17.2 & 5.2 & 45 & 45 & 600 \\
\hline & May & 17.8 & 3.8 & 30 & 50 & 700 \\
\hline & June & 18.2 & 1.7 & 10 & 25 & 750 \\
\hline & July & 19.3 & 0.8 & 5 & 25 & 700 \\
\hline & Average & 14.7 & 2.3 & 30.0 & 44.0 & 683.3 \\
\hline \multirow{6}{*}{2012} & March & 13.3 & 2.3 & 25 & 30 & 500 \\
\hline & April & 10.0 & -2.0 & 100 & 100 & 400 \\
\hline & May & 15.5 & 1.5 & 60 & 100 & 600 \\
\hline & June & 17.5 & 1.0 & 45 & 115 & 700 \\
\hline & July & 18.4 & -0.1 & 5 & 25 & 800 \\
\hline & Average & 14.9 & 2.7 & 47.0 & 74.0 & 600.0 \\
\hline \multirow{6}{*}{2013} & March & 10.1 & -0.9 & 280 & 350 & 300 \\
\hline & April & 12.2 & 0.2 & 100 & 100 & 550 \\
\hline & May & 13.1 & -0.9 & 50 & 80 & 650 \\
\hline & June & 17.9 & 1.4 & 50 & 125 & 700 \\
\hline & July & 21.0 & 3.5 & 10 & 50 & 900 \\
\hline & Average & 14.8 & 3.3 & 98.0 & 141.0 & 620.0 \\
\hline
\end{tabular}

$T_{\mathrm{m}}$ : mean monthly air temperature $\left({ }^{\circ} \mathrm{C}\right)$; TOD: temperature deviation from the long-year average (1971 to 2000$)\left({ }^{\circ} \mathrm{C}\right)$; Ppt: quantity of rainfall (mm); RP: quantify of rainfall in \% from the long-year average (1971 to 2000); RO: mean monthly sunshine irradiation $\left(\mathrm{MJ} \cdot \mathrm{m}^{-2}\right)$.

was expressed as MJ. $\mathrm{kg}^{-1} \mathrm{DM}$. All determinations were made in triplicate [24].

2.4. Extraction of Sugars and Organic Acids. For sugars and organic acids determinations, each freeze-dried sample was ground to a fine powder using a blender (model BL41, Waring Commercial, Torrington, CT, USA).

For the sugars' extraction, the benzoyl chloride derivatization method adapted from Daniel et al. [25] was used. From each cultivar $100 \mathrm{mg}$ of DM was extracted with $80 \%$ aqueous ethanol $(5 \mathrm{~mL})$ and placed at $20^{\circ} \mathrm{C}$ during $2 \mathrm{~h}$. After that, $1 \mathrm{~mL}$ of extract was transferred to another vial and all extracts were centrifuged at $13000 \mathrm{rpm}$ during $10 \mathrm{~min}$, at $4^{\circ} \mathrm{C}$ (model 2-16K, Sigma, Germany). $100 \mu \mathrm{L}$ of supernatant was placed in another vial and was dried with liquid nitrogen until complete evaporation. $500 \mu \mathrm{L}$ of derivatization reagent (10\% benzoyl in pyridine) was added and the mixture was heated at $37^{\circ} \mathrm{C}$ during $16 \mathrm{~h}$. After this, $1 \mathrm{~mL}$ of diethyl ether was added with agitation. All extracts were centrifuged at $13000 \mathrm{rpm}$ during $20 \mathrm{~min}$, at $4^{\circ} \mathrm{C}$. Then, $750 \mu \mathrm{L}$ of supernatant was placed in another vial and was dried with liquid nitrogen until complete evaporation. $750 \mu \mathrm{L}$ of $100 \%$ methanol was added and the extract was transferred into a vial and kept in $-20^{\circ} \mathrm{C}$ until being used in determination of free sugars by high-performance liquid chromatography (HPLC). The extraction procedure was repeated two times more for each cultivar.
For the organic acids determinations, the method suggested by Phillips et al. [26] was used. One gram of DM was homogenized into $10 \mathrm{~mL}$ of bidistilled water using a commercial sonicator (model Sonorex RK 100, Bandelin, Germany). After the extraction, the homogenate was centrifuged at $4000 \mathrm{rpm}$ for $15 \mathrm{~min}$ (model 2100 Kubota, Tokyo, Japan). The supernatant was filtered through a $0.20 \mu \mathrm{m}$ cellulose ester filter (Whatman ${ }^{\mathrm{TM}}$, Spartan 13/0.2 RC), transferred $1 \mathrm{~mL}$ into a vial, and kept in $-20^{\circ} \mathrm{C}$ until use in determination of organic acids by HPLC. The extraction procedure was repeated two times more for each cultivar.

2.5. Determination of Free Sugars and Organic Acids. The quantification of free sugars and organic acids was performed by HPLC analysis, using a HPLC system, equipped with a UV detector, mixing chamber (Gilson-mod. 811A, Middleton, WI, USA), two high pressure pumps (Gilson-mod. 305 and 306), automatic injector (Gilson-mod. 231XL, Middleton, WI, USA), injection unit (Gilson-mod. 402, Middleton, WI, USA), column chamber with controlled temperature (Jones Chromatography, Columbus, OH, USA), and a reverse phase column (C18 Spherisorb ODS2, $250 \mathrm{~mm} \times 4.6 \mathrm{~mm}$ ). For the free sugars, the eluent was constituted by water with $1 \%$ of trifluoroacetic acid (TFA) (solvent A) and acetonitrile with $1 \%$ TFA (solvent B). Elution was performed at a flow rate of solvent of $1 \mathrm{~mL} \cdot \mathrm{min}^{-1}$, with a gradient starting with $100 \%$ of water, and the injection volume of $20 \mu \mathrm{L}$. The identification was made comparing with external standards (Sigma-Aldrich) and based on their retention time and UV spectra. The chromatograms were recorded at $270 \mathrm{~nm}$. Three replicates were done for each cultivar. For the organic acids, the eluent was constituted by potassium dihydrogen phosphate $(6.8 \mathrm{~g} / \mathrm{L})$ with $85 \%$ orthophosphoric acid with $\mathrm{pH}$ adjusted to 2.1, under isocratic conditions. The flow rate was set to $0.8 \mathrm{~mL} \cdot \mathrm{min}^{-1}$ and the sample injection volume was $20 \mu \mathrm{L}$. The identification was made comparing with external standards (Sigma-Aldrich) and based on their retention times and UV spectra. The chromatograms were recorded at $210 \mathrm{~nm}$. Three replicates were done for each cultivar.

2.6. Determination of Vitamin C. For vitamin C determination, each freeze-dried sample was ground to a fine powder using a blender (model BL41, Waring Commercial, Torrington, CT, USA).

The vitamin $\mathrm{C}$ (ascorbic acid) content was analyzed by spectrophotometry based on the methods of Chun et al. [27], Sousa [28], and Barros et al. [29]. Twenty mg DM were extracted with 5\% metaphosphoric acid (Fluka) and placed under agitation at room temperature for $45 \mathrm{~min}$. All extracts were filtered (Whatman ${ }^{\mathrm{TM}}$ No. $1,90 \mathrm{~mm}$ ), and $1 \mathrm{~mL}$ of each extract was transferred to $10 \mathrm{~mL}$ tubes. Finally, to each extract $9 \mathrm{~mL}$ of 2.6 dichloroindophenol (Fluka), previously prepared, was added. Simultaneously a blank standard was prepared, which was made replacing vitamin $\mathrm{C}$ by $1 \mathrm{~mL}$ of $5 \%$ metaphosphoric acid. The absorbance of each reaction mixture was immediately measured in UV spectrophotometer (U-2000, serial 121-0120, Hitachi Ltd., Tokyo, Japan) at $515 \mathrm{~nm}$. The vitamin $C$ standard curve was obtained 
TABLE 2: Means of three years and two altitudes for fresh mass, volume, dry mass, crude protein, crude fat, and energy in four blueberry cultivars. Means $(n=36) \pm$ SEM (standard error of the mean).

\begin{tabular}{lcccccc}
\hline Cultivar & $\begin{array}{c}\text { Fresh mass } \\
(\mathrm{g})\end{array}$ & $\begin{array}{c}\text { Fresh volume } \\
(\mathrm{mL})\end{array}$ & $\begin{array}{c}\text { Dry mass } \\
\left(\mathrm{g} \cdot 100 \mathrm{~g}^{-1} \mathrm{DM}\right)\end{array}$ & $\begin{array}{c}\text { Crude protein } \\
\left(\mathrm{g} \cdot 100 \mathrm{~g}^{-1} \mathrm{DM}\right)\end{array}$ & $\begin{array}{c}\text { Crude fat } \\
\left(\mathrm{g} \cdot 100 \mathrm{~g}^{-1} \mathrm{DM}\right)\end{array}$ & $\begin{array}{c}\text { Energy } \\
\left.(\mathrm{M}) \cdot \mathrm{kg}^{-1} \mathrm{DM}\right)\end{array}$ \\
\hline Duke & $1.96 \pm 0.05^{\mathrm{b}}$ & $1.95 \pm 0.05^{\mathrm{b}}$ & $12.91 \pm 0.74^{\mathrm{a}}$ & $4.39 \pm 0.18^{\mathrm{b}}$ & $1.85 \pm 0.10^{\mathrm{b}}$ & $13.09 \pm 0.13^{\mathrm{a}}$ \\
Bluecrop & $1.93 \pm 0.05^{\mathrm{b}}$ & $1.87 \pm 0.07^{\mathrm{b}}$ & $14.74 \pm 0.21^{\mathrm{a}}$ & $5.33 \pm 0.23^{\mathrm{c}}$ & $2.37 \pm 0.15^{\mathrm{c}}$ & $13.10 \pm 0.08^{\mathrm{a}}$ \\
Goldtraube & $1.36 \pm 0.05^{\mathrm{a}}$ & $1.48 \pm 0.13^{\mathrm{a}}$ & $14.54 \pm 0.27^{\mathrm{a}}$ & $3.32 \pm 0.15^{\mathrm{a}}$ & $1.30 \pm 0.03^{\mathrm{a}}$ & $12.83 \pm 0.08^{\mathrm{a}}$ \\
Ozarkblue & $2.37 \pm 0.08^{\mathrm{c}}$ & $2.35 \pm 0.08^{\mathrm{c}}$ & $13.80 \pm 0.18^{\mathrm{a}}$ & $3.90 \pm 0.20^{\mathrm{ab}}$ & $1.70 \pm 0.11^{\mathrm{b}}$ & $12.89 \pm 0.13^{\mathrm{a}}$ \\
$p$ & 0.0001 & 0.0001 & 0.1366 & 0.0001 & 0.0001 & 0.3912 \\
\hline
\end{tabular}

Different letters indicate significantly different values at $p<0.05$.

$\left(y=-4.7914 x+0.908, R^{2}=0.977\right)$ for the calculation of vitamin C content. Vitamin C content was expressed as mg of vitamin $\mathrm{C}$ equivalent per $100 \mathrm{~g}^{-1} \mathrm{DM}$. The determination was made in triplicate for each cultivar.

2.7. Statistical Analysis. The data was statistically analyzed performing an analysis of variance (ANOVA). Significant differences were assessed with Duncan's multiple range test $(p<0.05)$. Pearson's correlation coefficients were estimated between climatic factors and quality parameters of the fruit and correlation plot was displayed in the circle of correlations. Principal Component Analysis (PCA) was also performed. Statistics were performed using PC software package SPSS (version 13.0; SPSS Inc.).

\section{Results and Discussion}

3.1. Biometric and Nutritional Parameters in Blueberry Cultivars. Results showed that the biometric and nutritional parameters (i.e., fresh mass, fresh volume, dry mass, crude protein, crude fat, and energy) did not differ between the blueberry cultivars and were not influenced by the growing sites' altitude.

However, the fruit fresh mass, fresh volume, crude protein, and crude fat varied significantly $(p<0.0001)$ among cultivars although their dry mass and energy content were very similar (Table 2). The fruit fresh mass varied between $1.4 \mathrm{~g}$ in "Goldtraube" and $2.4 \mathrm{~g}$ in "Ozarkblue." As expected, the fruit mass was positively correlated with volume (data not shown). Similar tendency and average values of fresh mass were found by Giovanelli and Buratti [11] for "Bluecrop" ( $0.8 \mathrm{~g})$ and "Goldtraube" (1.2 g) cultivars. Parra et al. [30] found variations between $0.8 \mathrm{~g}$ and $2.3 \mathrm{~g}$ of fruit weight in nine different highbush cultivars from 14 in southwest Spain. These authors related the variability to climate conditions and soil composition. Dry mass values ranged from 12.9 in "Duke" to $14.7 \mathrm{~g} \cdot 100 \mathrm{~g}^{-1}$ DM in "Bluecrop" fruits, corresponding to moisture content of $87.1 \%$ and $85.3 \%$, respectively. The variation detected among cultivars, although not statistically different, could be related to variations of the climate conditions throughout the years or could also depend on the genotype itself. Similarly, Prior et al. [8] and Starast et al.

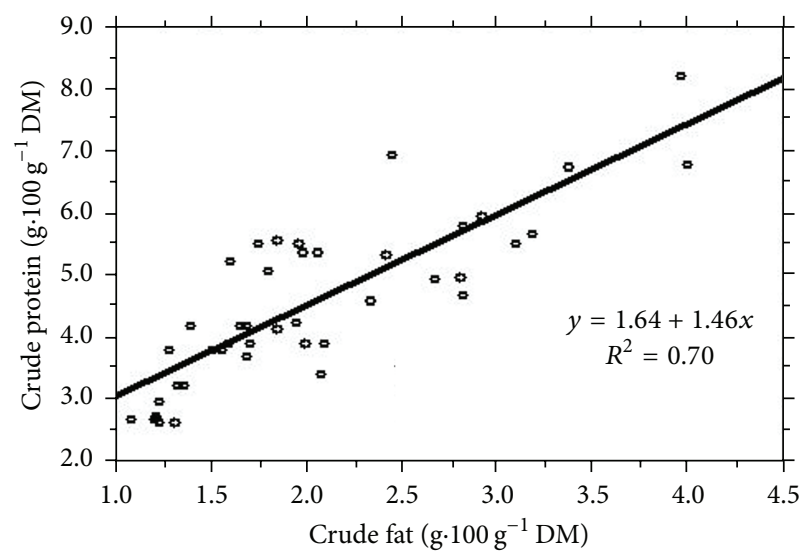

Figure 1: Correlation $(p<0.05)$ between the content of crude fat and crude protein $\left(\mathrm{g} \cdot 100 \mathrm{~g}^{-1} \mathrm{DM}\right)$ in four blueberry cultivars in three harvest years.

[14] also reported a significant influence of growing environmental conditions in berry moisture contents particularly immediately before the harvest that overlap the cultivar effect.

The crude protein content of the blueberries ranged from $3.3 \mathrm{~g} \cdot 100 \mathrm{~g}^{-1} \mathrm{DM}$ in "Goldtraube" to $5.3 \mathrm{~g} \cdot 100 \mathrm{~g}^{-1} \mathrm{DM}$ in "Bluecrop" (Table 2) and was higher than that reported (0.5$\left.0.7 \mathrm{~g} \cdot 100 \mathrm{~g}^{-1}\right)$ in previous studies [31]. The values founded in present study suggest that our climate and geographic conditions favored the accumulation of crude protein in blueberries, which is very interesting compared with the studies on "Duke" and "Bluecrop" cultivars carried out by Starast et al. [14] in Estonia.

The other parameter studied was the crude fat that varied between 1.3 and $2.4 \mathrm{~g} \cdot 100 \mathrm{~g}^{-1} \mathrm{DM}$ in "Goldtraube" and "Bluecrop" cultivars, respectively (Table 2). The scatter diagram of Figure 1 shows a significant positive relationship between crude protein and crude fat in the four blueberry cultivars, harvested in three years and different growth altitudes $\left(y=1.64+1.46 x ; R^{2}=0.70, p<0.05\right)$. The amounts of crude protein and crude fat as well as the total energy values obtained in our study are approximately 8 -fold higher than so far described in literature [14]. This tendency can be explained by the good adaptation of these highbush blueberries cultivars to the climatic conditions, 
soil composition, and altitude of the region where they are cultivated.

3.2. Free Sugars in Blueberry Cultivars. The predominant free sugars for each blueberry cultivars were fructose (68.5\%), follow by galactose $(15.5 \%)$ and glucose $(14.3 \%)$ and traces of sucrose (1.6\%). Our data are in accordance with results reported by Kalt and McDonald [12]. The low sucrose content in the blueberries is probably due to either the enzymatic hydrolysis or its conversion into other sugars during the ripening process.

The contents of glucose, galactose, fructose, sucrose, and total free sugars for each blueberry cultivar in each harvest year and altitude were evaluated (Table 3 ). No significant differences $(p>0.05)$ were found among cultivars for glucose, galactose, and total free sugars contents (Table 4 ). The "Ozarkblue" cultivar showed the highest total sugar content $\left(253.8 \mathrm{mg} \cdot \mathrm{g}^{-1} \mathrm{DM}\right)$, namely, the high glucose and galactose amounts, while "Bluecrop" cultivar had the lowest value $\left(238.1 \mathrm{mg} \cdot \mathrm{g}^{-1} \mathrm{DM}\right)$. Fructose ranged from $162.0 \mathrm{mg} \cdot \mathrm{g}^{-1}$ DM in "Goldtraube" to $178.2 \mathrm{mg} \cdot \mathrm{g}^{-1} \mathrm{DM}$ in "Duke" and sucrose was the individual sugar present in lower amount in all cultivars, ranging from $3.3 \mathrm{mg} \cdot \mathrm{g}^{-1} \mathrm{DM}$ in "Ozarkblue" to $5.6 \mathrm{mg} \cdot \mathrm{g}^{-1} \mathrm{DM}$ in "Goldtraube." Wang et al. [32] evaluated forty-two blueberry cultivars, including "Bluecrop" and "Duke" cultivars, and mentioned that there was a wide variation in sugar values between different growing seasons. In 2008 the main sugar content, fructose, ranged from $56.2 \mathrm{mg} \cdot \mathrm{g}^{-1} \mathrm{FW}$ in "Bluecrop" to $62.2 \mathrm{mg} \cdot \mathrm{g}^{-1} \mathrm{FW}$ in "Duke," whereas, in 2009, the fructose content varied between $43.1 \mathrm{mg} \cdot \mathrm{g}^{-1} \mathrm{FW}$ in "Bluecrop" and $49.2 \mathrm{mg} \cdot \mathrm{g}^{-1} \mathrm{FW}$ in "Duke" [32]. In our study, the levels of free sugars were higher than those reported by Wang et al. [32] which may be due to the involvement of sugars in ripening process with a large environmental component.

Fructose is more than 1.5 times sweeter than sucrose and is the sweetest of all naturally occurring carbohydrates and is the most water soluble of all sugars [33]. Although not as sweet as fructose, glucose is the primary energy source and is the main sugar used as precursor in biosynthesis of several important substances such as vitamins, proteins, and lipids.

Significant differences $(p<0.0001)$ in all free sugars were found within the 3 consecutive years (Table 4 ). The accumulation of total free sugars was higher in $2012\left(368.2 \mathrm{mg} \cdot \mathrm{g}^{-1}\right.$ $\mathrm{DM})$ and the lowest contents of all free sugars were observed in 2013 (Table 4). The year 2011 promoted the accumulation

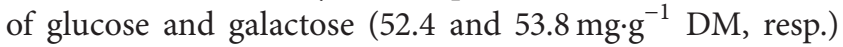
in blueberry cultivars and in the year 2012 the contents of fructose and sucrose (269.7 and $5.2 \mathrm{mg} \cdot \mathrm{g}^{-1} \mathrm{DM}$, resp.) were higher.

Seasonal differences in temperature and rainfall had large impact on the accumulation of sugars and other compounds $[34,35]$. The period between March and July 2011 showed similar values of temperature but lower rates of precipitation compared to the same period of 2012 and 2013 (Table 1), particularly near to the crop harvesting (June-July), which could explain the variations found in free sugars among the years and cultivars (Tables 3 and 4). Based on our results it seems that lower rainfall associated with higher solar radiation $\mathrm{RO}$ (Table 1) seems to favour the accumulation of free sugars. A linear tendency among years was not found but if the first and the third year of production are compared a decrease in glucose, galactose, and fructose can be observed in all cultivars in both altitudes. A similar trend was registered for sucrose in "Goldtraube" cultivar in high altitude (missing data in low altitude) and "Ozarkblue" cultivar in both altitudes (Table 3 ). These results suggest that the climate factors, rainfall, and temperature associated with radiation affect free sugars content.

In general, the altitude did not play an important role (Table 4 ) as it appears to affect only the sucrose content ( $p<$ $0.05)$ that was higher at higher altitude $\left(4.3 \mathrm{mg} \cdot \mathrm{g}^{-1} \mathrm{DM}\right)$ than at lower altitude $\left(3.1 \mathrm{mg} \cdot \mathrm{g}^{-1} \mathrm{DM}\right)$. Recent study verified that the altitude did not affect the soluble solid content (SSC) in strawberry as proposed by Guerrero-Chavez et al. [36]. Nevertheless, Mikulic-Petkovsek et al. [37] mentioned that bilberries growing in sites in low altitude contained higher levels of total sugars, compared with bilberry fruit in high altitude, which can be related to high light intensity of the location, contributing to increased photosynthetic activity and primary metabolite accumulation.

The interactions between the origins of variation cultivar $(\mathrm{Cv})$, years $(\mathrm{Y})$, and altitude $(\mathrm{A})$ were significantly different $(p<0.0001)$ for the interaction $\mathrm{Cv} * \mathrm{Y}$ in all free sugars and in total free sugars. The interaction $\mathrm{Cv} * \mathrm{~A}$ was significant $(p<0.05)$ only for sucrose and total free sugars. A significant $(p<0.05)$ interaction between cultivar, harvest year, and altitude on fructose, sucrose, and total free sugars contents was found (Table 3). For these parameters the highest fructose content and the highest total free sugars were found in the "Ozarkblue" cultivar in 2012 at low altitude $\left(304.5 \mathrm{mg} \cdot \mathrm{g}^{-1}\right.$ $\mathrm{DM}$ and $413.8 \mathrm{mg} \cdot \mathrm{g}^{-1} \mathrm{DM}$, resp.) and the highest amount of sucrose in the "Goldtraube" cultivar in 2011 at high altitude (missing data in low altitude) $\left(7.9 \mathrm{mg} \cdot \mathrm{g}^{-1} \mathrm{DM}\right)$.

3.3. Organic Acids in Blueberry Cultivars. The contents of quinic acid, malic acid, citric acid, and total organic acids in the four blueberry cultivars grown at two altitudes and harvest in three years are presented in Table 3. The mean organic acid composition for the four blueberry cultivars was citric acid $83.7 \%$, quinic acid $10.9 \%$, and malic acid 5.4\%. Ehlenfeldt et al. [21] reported that highbush blueberries are characterized by high citric acid values (around $80 \%$ ) and a small concentration of succinic, quinic, and malic acids.

Significant differences $(p>0.05)$ among cultivars in the contents of quinic acid, citric, acid and total organic acid were found (Table 4). The "Duke" cultivar had the highest quinic acid content $\left(7.1 \mathrm{mg} \cdot \mathrm{g}^{-1} \mathrm{DM}\right)$ and the "Bluecrop" cultivar had the lowest one $\left(5.4 \mathrm{mg} \cdot \mathrm{g}^{-1} \mathrm{DM}\right)$. Citric acid ranged from $28.7 \mathrm{mg} \cdot \mathrm{g}^{-1} \mathrm{DM}$ in "Duke" to $61.5 \mathrm{mg} \cdot \mathrm{g}^{-1} \mathrm{DM}$ in "Goldtraube." The total organic acids content ranged from $39.4 \mathrm{mg} \cdot \mathrm{g}^{-1} \mathrm{DM}$ in "Duke" to $70.3 \mathrm{mg} \cdot \mathrm{g}^{-1} \mathrm{DM}$ in "Goldtraube." The amounts of organic acids such as citric and malic acid described for cultivars "Duke" and "Bluecrop" by Wang et al. [32] are lower than that obtained in our work and in general for highbush blueberries [17]. Organic acids 


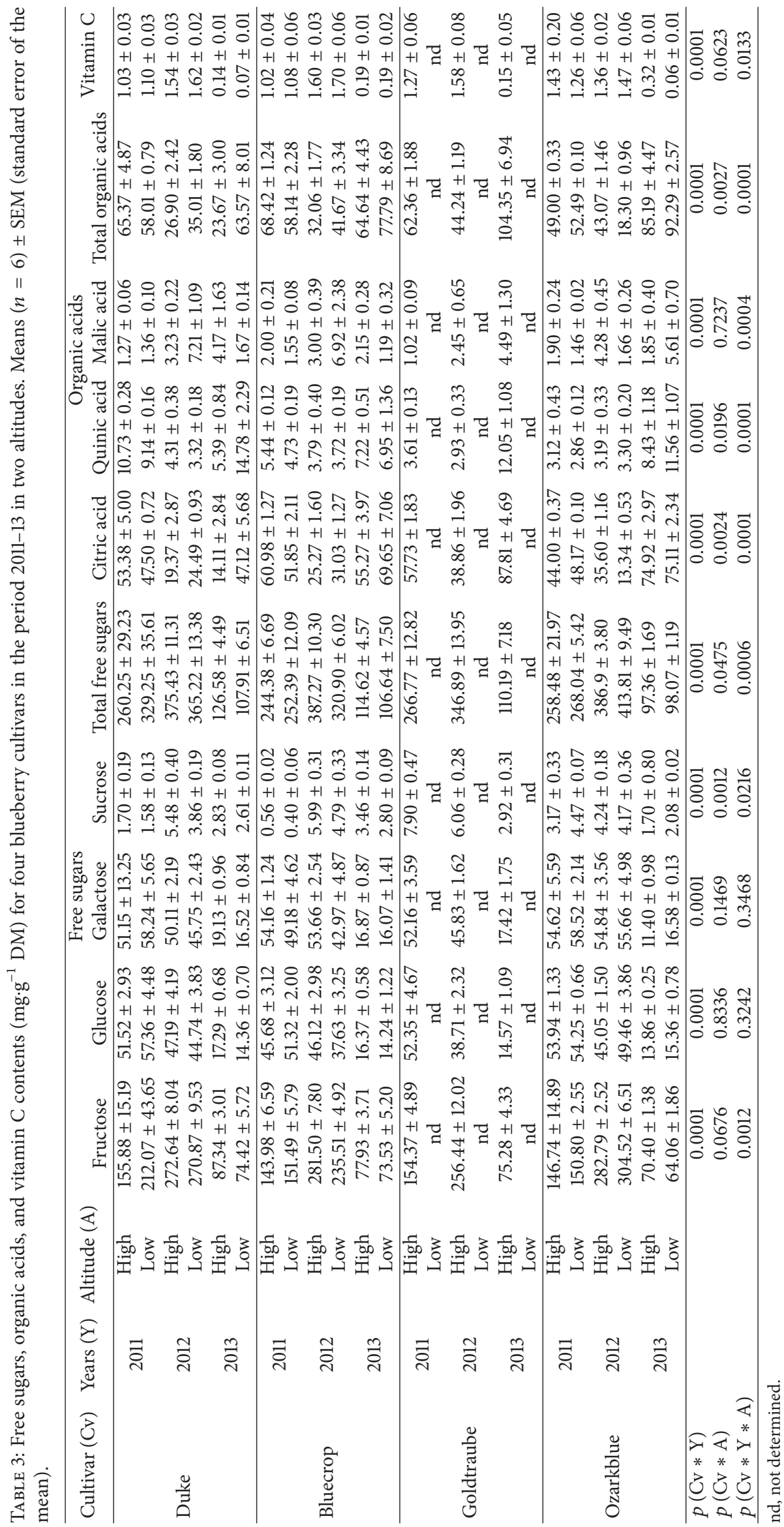




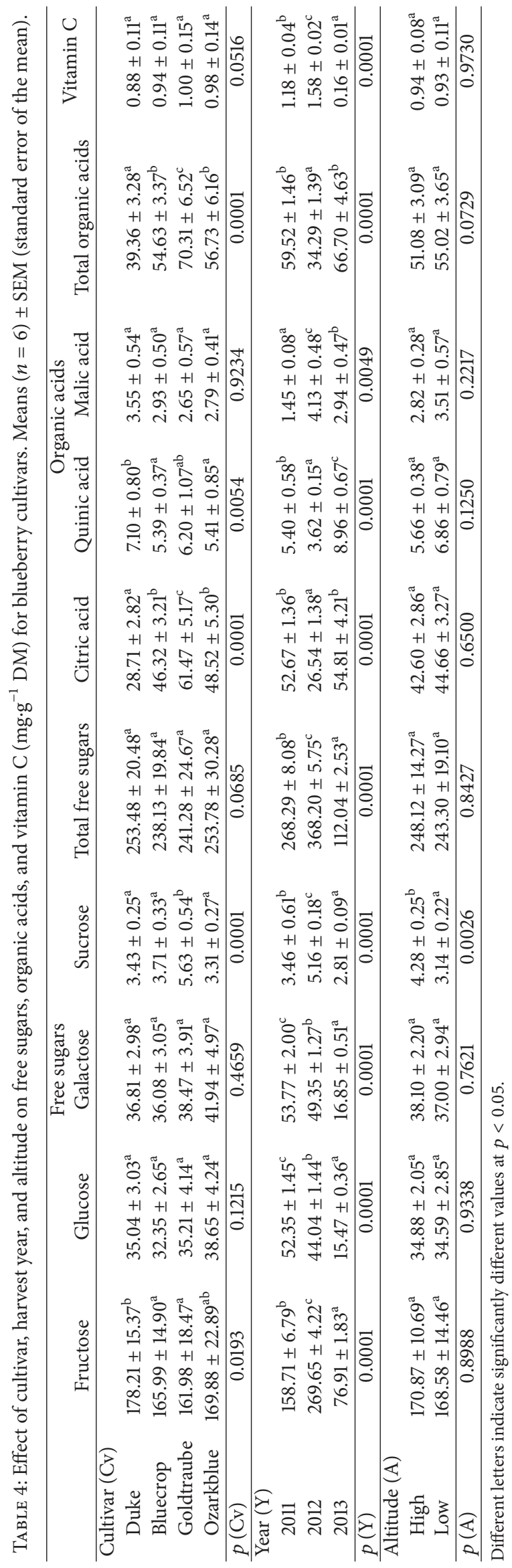


are related to maturation, in particular malic acid, which confers the bitter taste, although the amount decreases with increasing fruit ripeness. Previous studies done by Kafkas et al. [38] reported in blackberries values of malic acid content (4.0 $\left.\mathrm{mg} \cdot \mathrm{g}^{-1} \mathrm{DM}\right)$ similar to our results.

Significant differences $(p<0.05)$ in all organic acids were found within years (Table 4). As climate conditions seem to have influence on the accumulation of sugars in blueberries, also organic acids appear to be affected by the harvest year. The contents of quinic and citric acids were higher in 2013 (9.0 and $54.8 \mathrm{mg} \cdot \mathrm{g}^{-1} \mathrm{DM}$, resp.) when comparing with the other two years of harvest (2011 and 2012). In the year 2012 the content of malic acid was the highest ( $\left.4.1 \mathrm{mg} \cdot \mathrm{g}^{-1} \mathrm{DM}\right)$ but the higher accumulation of total organic acids was in 2013 (66.7 $\left.\mathrm{mg} \cdot \mathrm{g}^{-1} \mathrm{DM}\right)$. The citric acid was negatively correlated with fructose which was expected as during ripeness stage the sugar contents increase and organic acids contents decrease (data not shown $[39,40]$ ).

No significant impact of two different altitudes on threeyear mean values of the studied chemical parameters was found (Table 4). Conversely, Mikulic-Petkovsek et al. [37] reported that bilberry fruits from high altitude had more organic acids content, compared with bilberry fruit from in low altitude.

When evaluating the interactions between different origins of variation ( $\mathrm{CV}, \mathrm{Y}$, and $\mathrm{A})$, a significant influence of the $\mathrm{Cv} * \mathrm{Y}$ interaction on single as well as total organic acids contents was observed (Table 3). Indeed, in 2012 the "Goldtraube" cultivar grown at higher altitude showed the highest values of citric acids and total organic acids (87.8 and $104.4 \mathrm{mg} \cdot \mathrm{g}^{-1} \mathrm{DM}$, resp.) while the "Ozarkblue" cultivar, at lower altitude, showed the lowest values $\left(13.3 \mathrm{mg} \cdot \mathrm{g}^{-1} \mathrm{DM}\right.$ to citric acid and $18.3 \mathrm{mg} \cdot \mathrm{g}^{-1} \mathrm{DM}$ to total acids).

3.4. Vitamin $C$ in Blueberry Cultivars. The vitamin $C$ was detected in all cultivars and its content ranged from $0.88 \mathrm{mg} \cdot \mathrm{g}^{-1} \mathrm{DM}$ in "Duke" to $1.0 \mathrm{mg} \cdot \mathrm{g}^{-1} \mathrm{DM}$ in "Goldtraube" (Table 4$)$. There were no significant differences $(p>0.05)$ in the concentration of vitamin $\mathrm{C}$ among the four blueberry cultivars. Prior et al. [8] found vitamin C content of $7.2 \mathrm{mg} \cdot 100 \mathrm{~g}^{-1} \mathrm{DM}$ in "Duke" and $8.1 \mathrm{mg} \cdot 100 \mathrm{~g}^{-1} \mathrm{DM}$ in "Bluecrop" while Sinelli et al. [41] referred values of vitamin C between 0.05 and $8.0 \mathrm{mg} \cdot 100 \mathrm{~g}^{-1} \mathrm{DM}$ in highbush blueberries. Kafkas et al. [38] evaluated the content of vitamin $\mathrm{C}$ in five blackberry cultivars and its concentration varied between 2.5 and $14.9 \mathrm{mg} \cdot \mathrm{g}^{-1} \mathrm{DM}$. In all of these studies, a significant variability among cultivars was observed.

The content of vitamin $\mathrm{C}$ was also evaluated over the three years at the different altitudes (Table 4). Results showed a higher variation in vitamin $\mathrm{C}$ content with the year of harvest $(p<0.0001)$ than with altitudes $(p>0.05)$. The content of vitamin C (1.6 mg.g $\left.{ }^{-1} \mathrm{DM}\right)$ was higher in 2012 comparing with the other two years (2011 and 2013). In general, in horticultural crops, light intensities increase the content of vitamin C [9]. In 2011 and 2012 there was, on average, a higher value of millijoule per square meter for solar radiation and bright sunshine duration in hours than in 2013 (Table 1).
These results seem to confirm that altitude did not play an important role in vitamin $\mathrm{C}$ synthesis and for other organic compounds, whilst light, temperature, and precipitation (climate conditions) seem to have more influence.

Results showed significant interactions between different origins of variation $(\mathrm{Cv}, \mathrm{Y}$, and $\mathrm{A}), \mathrm{Cv} * \mathrm{Y} * \mathrm{~A}$ and $\mathrm{Cv} * \mathrm{Y}$ on vitamin $\mathrm{C}$ content (Table 3 ). In fact, the highest content of vitamin C (1.7 mg. ${ }^{-1}$ DM in "Bluecrop" cultivar in 2012) and the lowest one $\left(0.06 \mathrm{mg} \cdot \mathrm{g}^{-1} \mathrm{DM}\right.$ in "Ozarkblue" cultivar in 2013) were obtained at low altitude.

3.5. Principal Component Analysis. All the nutritional and chemical composition data of the four blueberry cultivars in the three consecutive years of study in the two altitudes and climatic factors were evaluated using the Principal Component Analysis (PCA). This analysis allowed us to correlate the climatic factors and quality parameters of the fruits. In a PCA, if the first three components accumulate a percentage, in general above $70 \%$ of the total variation, they satisfactorily explain the variability among the samples tested [42].

The two first components of PCA showed that fructose, glucose, galactose, and vitamin $\mathrm{C}$ were positively connected (Figure 2(a)) in a 77.4\% of probability. Galdón et al. [39] and Ramaiya et al. [43] have also reported a high and positive correlation between sugars and vitamin $\mathrm{C}$. Citric and quinic acids were negatively correlated in principal component 1 (PC1), while the malic acid was positively correlated with PC1 and PC2. The correlation between malic acid and other acids was negative. These results showed a direct association between free sugars and vitamin $\mathrm{C}$ contents and between citric and quinic acids. Free sugars were in general positively correlated with each other and negatively associated with organic acids. This tendency confirms the idea that, with fruit growth, organic acids are degraded and sourness decreases, while sugars are synthesized and sweetness increases.

A PCA (Figure 2(b)) integrating total free sugars, total organic acids, fresh volume, quantity of rainfall (Ppt), mean temperature $\left(T_{\mathrm{m}}\right)$, maximum temperature $\left(T_{\max }\right)$, and minimum temperature $\left(T_{\min }\right)$ was performed. In this analysis, the first component accounted for $36.6 \%$ of the total variance and the second for $28.2 \%$, representing the first two factorial axes (PC1 and PC2) $64.8 \%$ of the total variance (Figure 2(b)). Since this value was lower than $70 \%$, the analysis including the PC3 was also performed (Figure 2(c)). In Figures 2(b) and 2 (c), it was possible to verify the formation of three groups. The correlation between total free sugars with energy was positive. This could explain why the major source of energy in blueberries is sugars. This is very important from nutritional point of view because blueberries can have content of energy with low content of crude fat. Total free sugars, energy, and temperature were positively correlated in PC1 which could explain the association between the temperatures increase with the accumulation of free sugars (Figure 2(b)). The quantity of rainfall and fruit fresh volume was positively correlated in PC2 and PC3 (Figures 2(b) and 2(c)) that showed a direct association between the precipitation and blueberries' volume. The total free sugars were positively correlated in PC1 and PC2 but negatively in PC3 and the total 


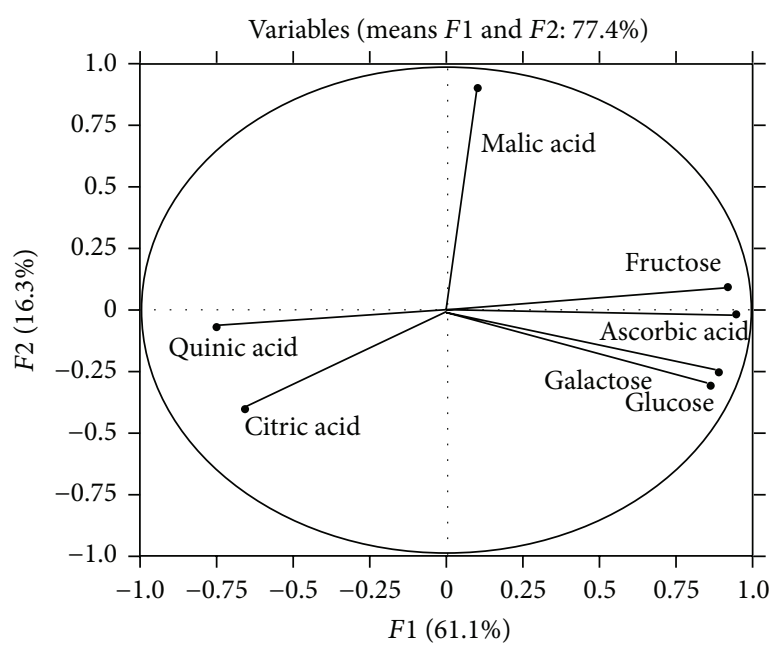

(a)

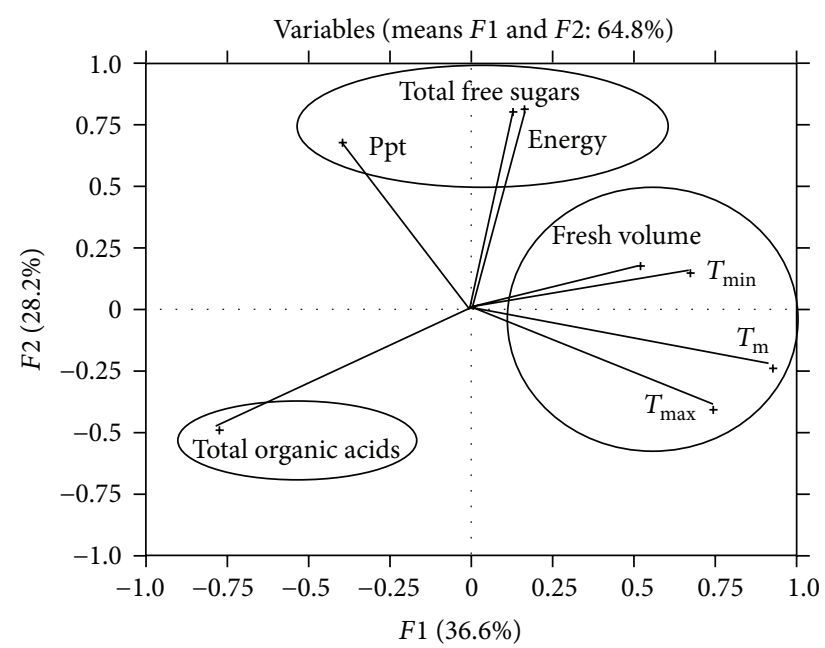

(b)

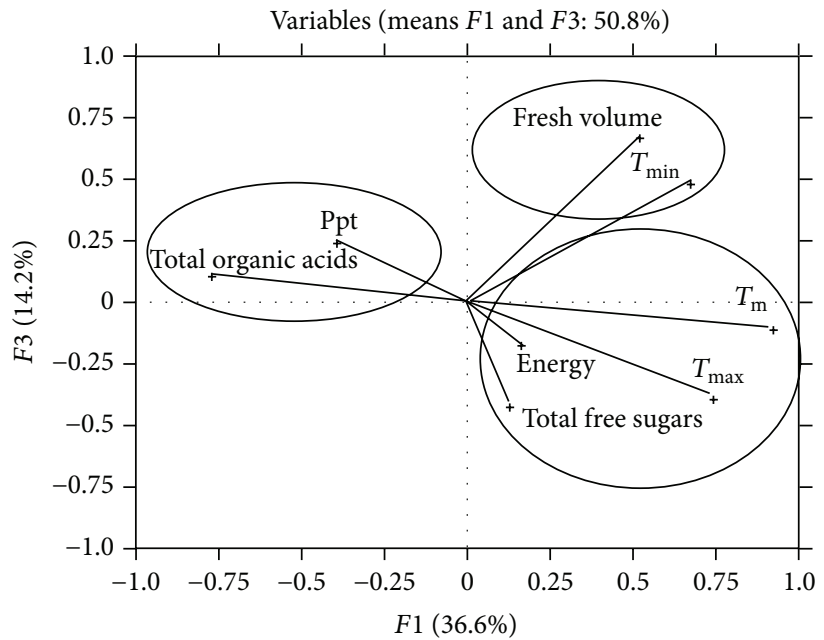

(c)

FIgURE 2: (a) Principal Component Analysis (PCA) obtained by analysis of free sugars, organic acids, and vitamin C data for four blueberry cultivars harvested in 2011-13. ((b) and (c)) Principal Component Analysis (PCA) obtained by analysis of total free sugars, total organic acids, fresh volume, Ppt (quantity of rainfall), $T_{\mathrm{m}}$ (mean temperature), $T_{\max }$ (maximum temperature), and $T_{\min }$ (minimum temperature) data for four blueberry cultivars harvested in 2011-13.

organic acids were negatively correlated in PC1 and PC2 and positively in PC3 (Figures 2(b) and 2(c)).

Studies related to altitude have given contradictory results in terms of fruit quality as phenolic compounds content [44-46]. Rieger et al. [44] mentioned that the content of anthocyanins in bilberries decreased alongside increasing altitude. Conversely, Martz et al. [45] reported that leaves of plants growing in higher altitudes (high-light-intensity sites) accumulate more total phenolics than plants growing in lower altitudes (low-light-intensity sites). Zoratti et al. [46] reported that there was an increasing accumulation of anthocyanins in wild bilberries and highbush blueberry alongside increasing altitude. However, the accumulation was due to a significant increase in delphinidin and malvidin glycosides, whereas the accumulation of cyanidin and peonidin glycosides was not affected by altitude. Nevertheless, seasonal differences, especially temperature, had a major influence on the accumulation of sugar, organic acids, and anthocyanins in blueberries.

In conclusion, the blueberries are exceptionally rich sources of vitamin $\mathrm{C}$ and organic acids and poor in fat presenting an interesting nutritional alternative. The fructose and the glucose were the predominant sugars and citric acid was the major organic acid. The "Ozarkblue" cultivar had higher mass and volume and the "Bluecrop" cultivar was the richest in protein and fat. The fructose sugar was present in greater amounts in "Duke" cultivar and the "Goldtraube" cultivar (missing data in low altitude) features more sucrose and organic acids. Free sugars, organic acids, and vitamin $\mathrm{C}$ contents were significantly influenced by the harvest year and climate conditions but the altitude did not seem to have much influence on blueberry quality. Based on PCA, free sugars were positively correlated each other with vitamin $\mathrm{C}$ and energy and showed a negative correlation 
with organic acids (citric and quinic acids). In blueberries, the accumulation of free sugars and the energy content increase with the temperature and the fresh volume increases with the rainfall. Blueberry fruits have vitamin $\mathrm{C}$, since it in combination with other compounds, namely, phenolics, is responsible for the fruit antioxidant proprieties. These quality attributes present a great opportunity for genetic improvement of blueberries through breeding programs. Our findings together with several reports [47-51] on berry primary and secondary metabolites reinforce the knowledge about the nutritional value of blueberries as acting as natural antimicrobial and health protect agents which could offer many new applications as functional foods for the consumers, in food industry and medicine.

\section{Abbreviations}

CF: $\quad$ Crude fat

CP: $\quad$ Crude protein

DM: Dry mass

HPLC: High-performance liquid chromatography

IPMA: Institute of the Atmosphere and the Sea

PCA: Principal Component Analysis

Ppt: Quantity of rainfall

SNIRH: National Information System for Hydric Resources

TFA: Trifluoroacetic acid

$T_{\mathrm{m}}$ : $\quad$ Mean temperature

$T_{\max }: \quad$ Maximum temperature

$T_{\min }$ : Minimum temperature.

\section{Additional Points}

(i) Impact of the harvest year and altitude was evaluated in four blueberry cultivars. (ii) Differences on chemical traits were found among the harvest years and cultivars. (iii) The altitude had no significant influence on blueberry quality. (iv) Citric acid was the main organic acid in blueberries. (v) Fructose was the most abundant sugar in blueberries.

\section{Competing Interests}

The authors declare that they have no competing interests.

\section{Acknowledgments}

This study was supported by AdI/COMPETE/QREN/EU Project “Mirtilo com Inovação” no. 13736.

\section{References}

[1] Š. Može, T. Polak, L. Gašperlin et al., "Phenolics in slovenian bilberries (Vaccinium myrtillus L.) and blueberries (Vaccinium corymbosum L.)," Journal of Agricultural and Food Chemistry, vol. 59, no. 13, pp. 6998-7004, 2011.

[2] J. B. Retamales and J. F. Hancock, "Growth of the blueberry industry outside North America," in Blueberries, S. Hulbert, Ed., vol. 21 of Crop Production Science Horticulture, pp. 1-19, CABI, London, UK, 2012.
[3] I. Badjakov, M. Nikolova, R. Gevrenova, V. Kondakova, E. Todorovska, and A. Atanassov, "Bioactive compounds in small fruits and their influence on human health," Biotechnology and Biotechnological Equipment, vol. 22, no. 1, pp. 581-587, 2008.

[4] F. Giampieri, S. Tulipani, J. M. Alvarez-Suarez, J. L. Quiles, B. Mezzetti, and M. Battino, "The strawberry: composition, nutritional quality, and impact on human health," Nutrition, vol. 28, no. 1, pp. 9-19, 2012.

[5] A. Faria, J. Oliveira, P. Neves et al., "Antioxidant properties of prepared blueberry (Vaccinium myrtillus) extracts," Journal of Agricultural and Food Chemistry, vol. 53, no. 17, pp. 6896-6902, 2005.

[6] J. Scalzo, A. Politi, N. Pellegrini, B. Mezzetti, and M. Battino, "Plant genotype affects total antioxidant capacity and phenolic contents in fruit," Nutrition, vol. 21, no. 2, pp. 207-213, 2005.

[7] H. Wang, G. Cao, and R. L. Prior, "Total antioxidant capacity of fruits," Journal of Agricultural and Food Chemistry, vol. 44, no. 3, pp. 701-705, 1996.

[8] R. L. Prior, G. Cao, A. Martin et al., "Antioxidant capacity as influenced by total phenolic and anthocyanin content, maturity, and variety of vaccinium species," Journal of Agricultural and Food Chemistry, vol. 46, no. 7, pp. 2686-2693, 1998.

[9] S. K. Lee and A. A. Kader, "Preharvest and postharvest factors influencing vitamin C content of horticultural crops," Postharvest Biology and Technology, vol. 20, no. 3, pp. 207-220, 2000.

[10] S. H. Häkkinen and A. R. Törrönen, "Content of flavonols and selected phenolic acids in strawberries and Vaccinium species: influence of cultivar, cultivation site and technique," Food Research International, vol. 33, no. 6, pp. 517-524, 2000.

[11] G. Giovanelli and S. Buratti, "Comparison of polyphenolic composition and antioxidant activity of wild Italian blueberries and some cultivated varieties," Food Chemistry, vol. 112, no. 4, pp. 903-908, 2009.

[12] W. Kalt and J. E. McDonald, "Chemical composition of lowbush blueberry cultivars," Journal of the American Society for Horticultural Science, vol. 121, no. 1, pp. 142-146, 1996.

[13] R. Beaudry, "Blueberry quality characteristics and how they can be optimized," in Annual Report of the Michigan State Horticultural Society (122nd), pp. 140-145, Michigan State Horticultural Society, Morrice, Mich, USA, 1992.

[14] M. Starast, K. Karp, E. Vool, U. Moor, T. Tonutare, and T. Paal, "Chemical composition and quality of cultivated and natural blueberry fruit in estonia," Vegetable Crops Research Bulletin, vol. 66, pp. 143-153, 2007.

[15] B. M. Silva, P. B. Andrade, G. C. Mendes, R. M. Seabra, and M. A. Ferreira, "Study of the organic acids composition of quince (Cydonia oblonga Miller) fruit and jam," Journal of Agricultural and Food Chemistry, vol. 50, no. 8, pp. 2313-2317, 2002.

[16] E. Kafkas, M. Koşar, S. Paydaş, S. Kafkas, and K. H. C. Başer, "Quality characteristics of strawberry genotypes at different maturation stages," Food Chemistry, vol. 100, no. 3, pp. 12291236, 2007.

[17] M. Mikulic-Petkovsek, V. Schmitzer, A. Slatnar, F. Stampar, and R. Veberic, "Composition of sugars, organic acids, and total phenolics in 25 wild or cultivated berry species," Journal of Food Science, vol. 77, no. 10, pp. C1064-C1070, 2012.

[18] J. G. Bordonaba and L. A. Terry, "Manipulating the taste-related composition of strawberry fruits (Fragaria $\mathrm{x}$ ananassa) from different cultivars using deficit irrigation," Food Chemistry, vol. 122, no. 4, pp. 1020-1026, 2010. 
[19] T. Mahmood, F. Anwar, M. Abbas, M. C. Boyce, and N. Saari, "Compositional variation in sugars and organic acids at different maturity stages in selected small fruits from Pakistan," International Journal of Molecular Sciences, vol. 13, no. 2, pp. 1380-1392, 2012.

[20] W. Routray and V. Orsat, "Blueberries and their anthocyanins: factors affecting biosynthesis and properties," Comprehensive Reviews in Food Science and Food Safety, vol. 10, no. 6, pp. 303320, 2011.

[21] M. K. Ehlenfeldt, F. I. Meredith, and J. R. Ballington, "Unique organic acid profile of rabbiteye vs. highbush blueberries," HortScience, vol. 29, no. 4, pp. 321-323, 1994.

[22] W. Kalt, D. A. J. Ryan, J. C. Duy, R. L. Prior, M. K. Ehlenfeldt, and S. P. Vander Kloet, "Interspecific variation in anthocyanins, phenolics, and antioxidant capacity among genotypes of highbush and lowbush blueberries (Vaccinium section Cyanococcus spp.)," Journal of Agricultural and Food Chemistry, vol. 49, no. 10, pp. 4761-4767, 2001.

[23] R. A. Moyer, K. E. Hummer, C. E. Finn, B. Frei, and R. E. Wrolstad, "Anthocyanins, phenolics, and antioxidant capacity in diverse small fruits: Vaccinium, Rubus, and Ribes," Journal of Agricultural and Food Chemistry, vol. 50, no. 3, pp. 519-525, 2002.

[24] AOAC, Official Methods of Analysis, Association of Official Analytical Chemists, Gaithersburg, Md, USA, 18th edition, 2006.

[25] P. F. Daniel, D. F. De Feudis, I. T. Lott, and R. H. McCluer, "Quantitative microanalysis of oligosaccharides by highperformance liquid chromatography," Carbohydrate Research, vol. 97, no. 2, pp. 161-180, 1981.

[26] M. M. Phillips, R. J. Case, C. A. Rimmer et al., "Determination of organic acids in Vaccinium berry standard reference materials," Analytical and Bioanalytical Chemistry, vol. 398, no. 1, pp. 425434, 2010.

[27] O. K. Chun, N. Smith, A. Sakagawa, and C. Y. Lee, "Antioxidant properties of raw and processed cabbages," International Journal of Food Sciences and Nutrition, vol. 55, no. 3, pp. 191-199, 2004.

[28] J. A. Sousa, Aulas Práticas de Química e Bioquímica dos Alimentos ( $1^{\circ}$ Módulo). Licenciatura em Tecnologia e Segurança Alimentar, Universidade Nova de Lisboa, Faculdade de Ciências e Tecnologia, Departamento de Química-Secção de Química Orgânica Aplicada, Lisboa, Portugal, 2005.

[29] L. Barros, M.-J. Ferreira, B. Queirós, I. C. F. R. Ferreira, and P. Baptista, "Total phenols, ascorbic acid, $\beta$-carotene and lycopene in Portuguese wild edible mushrooms and their antioxidant activities," Food Chemistry, vol. 103, no. 2, pp. 413-419, 2007.

[30] R. Parra, Z. D. Lifante, and B. Valdés, "Fruit size and picking scar size in some blueberry commercial cultivars and hybrid plants grown in SW Spain," International Journal of Food Science and Technology, vol. 42, no. 7, pp. 880-886, 2007.

[31] F. Kader, B. Rovel, M. Girardin, and M. Metche, "Composition of the fruit of highbush blueberry (Vaccinium corymbosum L.) grown in the East of France (Vosges)," Sciences des Aliments, vol. 14, pp. 281-290, 1994.

[32] S. Y. Wang, H. Chen, M. J. Camp, and M. K. Ehlenfeldt, "Genotype and growing season influence blueberry antioxidant capacity and other quality attributes," International Journal of Food Science and Technology, vol. 47, no. 7, pp. 1540-1549, 2012.

[33] L. M. Hanover and J. S. White, "Manufacturing, composition, and applications of fructose," The American Journal of Clinical Nutrition, vol. 58, no. 5, pp. 724S-732S, 1993.
[34] C. E. Sams, "Preharvest factors affecting postharvest texture," Postharvest Biology and Technology, vol. 15, no. 3, pp. 249-254, 1999.

[35] S. S. Panda, J. Martin, and G. Hoogenboom, "Blueberry crop growth analysis using climatologic factors and multi-temporal remotely sensed imagery," in Proceedings of the Georgia Water Resources Conference, University of Georgia, Athens, Ga, USA, April 2011.

[36] G. Guerrero-Chavez, M. Scampicchio, and C. Andreotti, "Influence of the site altitude on strawberry phenolic composition and quality," Scientia Horticulturae, vol. 192, pp. 21-28, 2015.

[37] M. Mikulic-Petkovsek, V. Schmitzer, A. Slatnar, F. Stampar, and R. Veberic, "A comparison of fruit quality parameters of wild bilberry (Vaccinium myrtillus L.) growing at different locations," Journal of the Science of Food and Agriculture, vol. 95, no. 4, pp. 776-785, 2015.

[38] E. Kafkas, M. Koşar, N. Türemiş, and K. H. C. Başer, "Analysis of sugars, organic acids and vitamin $\mathrm{C}$ contents of blackberry genotypes from Turkey," Food Chemistry, vol. 97, no. 4, pp. 732736, 2006.

[39] B. R. Galdón, D. R. Mesa, M. Elena, R. Rodríguez, and C. D. Romero, "Influence of the cultivar on the organic acid and sugar composition of potatoes," Journal of the Science of Food and Agriculture, vol. 90, no. 13, pp. 2301-2309, 2010.

[40] J. Zheng, B. Yang, M. Trépanier, and H. Kallio, "Effects of genotype, latitude, and weather conditions on the composition of sugars, sugar alcohols, fruit acids, and ascorbic acid in sea buckthorn (Hippophaë rhamnoides ssp. mongolica) berry juice," Journal of Agricultural and Food Chemistry, vol. 60, no. 12, pp. 3180-3189, 2012.

[41] N. Sinelli, A. Spinardi, V. Di Egidio, I. Mignani, and E. Casiraghi, "Evaluation of quality and nutraceutical content of blueberries (Vaccinium corymbosum L.) by near and mid-infrared spectroscopy," Postharvest Biology and Technology, vol. 50, no. 1, pp. 31-36, 2008.

[42] K. V. Mardia, J. T. Kent, and J. M. Bibby, Multivariate Analysis, vol. 521, Academic Press, London, UK, 1979.

[43] S. D. Ramaiya, J. S. Bujang, M. H. Zakaria, W. S. King, and M. A. S. Sahrir, "Sugars, ascorbic acid, total phenolic content and total antioxidant activity in passion fruit (Passiflora) cultivars," Journal of the Science of Food and Agriculture, vol. 93, no. 5, pp. 1198-1205, 2013.

[44] G. Rieger, M. Müller, H. Guttenberger, and F. Bucar, "Influence of altitudinal variation on the content of phenolic compounds in wild populations of Calluna vulgaris, Sambucus nigra, and Vaccinium myrtillus," Journal of Agricultural and Food Chemistry, vol. 56, no. 19, pp. 9080-9086, 2008.

[45] F. Martz, L. Jaakola, R. Julkunen-Tiitto, and S. Stark, "Phenolic composition and antioxidant capacity of bilberry (Vaccinium myrtillus) leaves in northern Europe following foliar development and along environmental gradients," Journal of Chemical Ecology, vol. 36, no. 9, pp. 1017-1028, 2010.

[46] L. Zoratti, L. Jaakola, H. Häggman, and L. Giongo, "Anthocyanin profile in berries of wild and cultivated Vaccinium spp. along altitudinal gradients in the Alps," Journal of Agricultural and Food Chemistry, vol. 63, no. 39, pp. 8641-8650, 2015.

[47] S. Vendrame, S. Guglielmetti, P. Riso, S. Arioli, D. Klimis-Zacas, and M. Porrini, "Six-week consumption of a wild blueberry powder drink increases Bifidobacteria in the human gut," Journal of Agricultural and Food Chemistry, vol. 59, no. 24, pp. 12815-12820, 2011. 
[48] N. P. Seeram, "Berries and human health: research highlights from the fifth biennial berry health benefits symposium," Journal of Agricultural and Food Chemistry, vol. 62, no. 18, pp. 3839-3841, 2014.

[49] S. Norberto, S. Silva, M. Meireles, A. Faria, M. Pintado, and C. Calhau, "Blueberry anthocyanins in health promotion: a metabolic overview," Journal of Functional Foods, vol. 5, no. 4, pp. 1518-1528, 2013.

[50] S. H. Nile and S. W. Park, "Edible berries: bioactive components and their effect on human health," Nutrition, vol. 30, no. 2, pp. 134-144, 2014.

[51] F. Giampieri, J. M. Alvarez-Suarez, and M. Battino, "Strawberry and human health: effects beyond antioxidant activity," Journal of Agricultural and Food Chemistry, vol. 62, no. 18, pp. 38673876, 2014. 

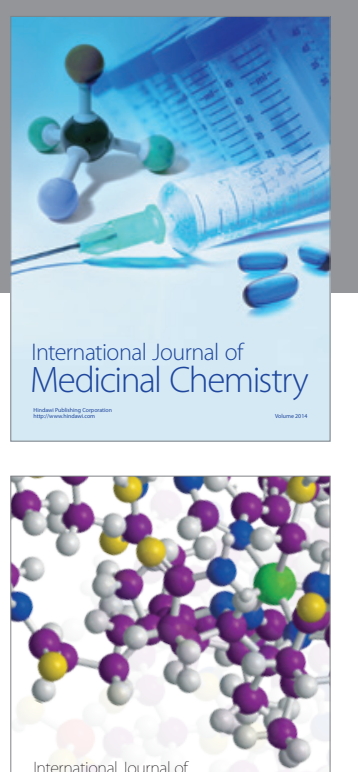

Carbohydrate Chemistry

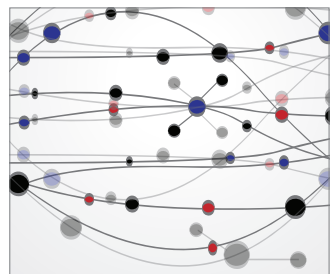

The Scientific World Journal
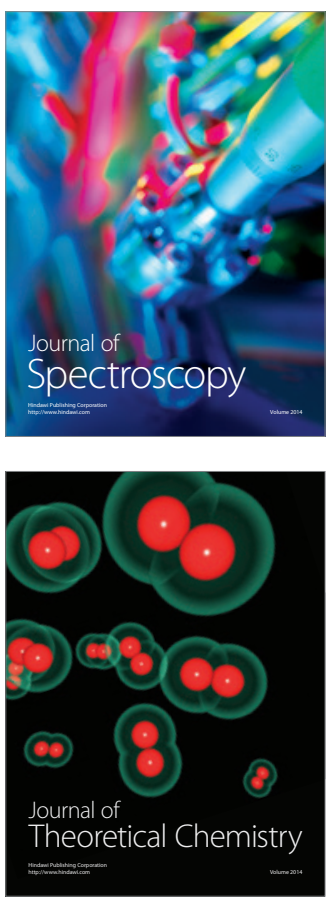
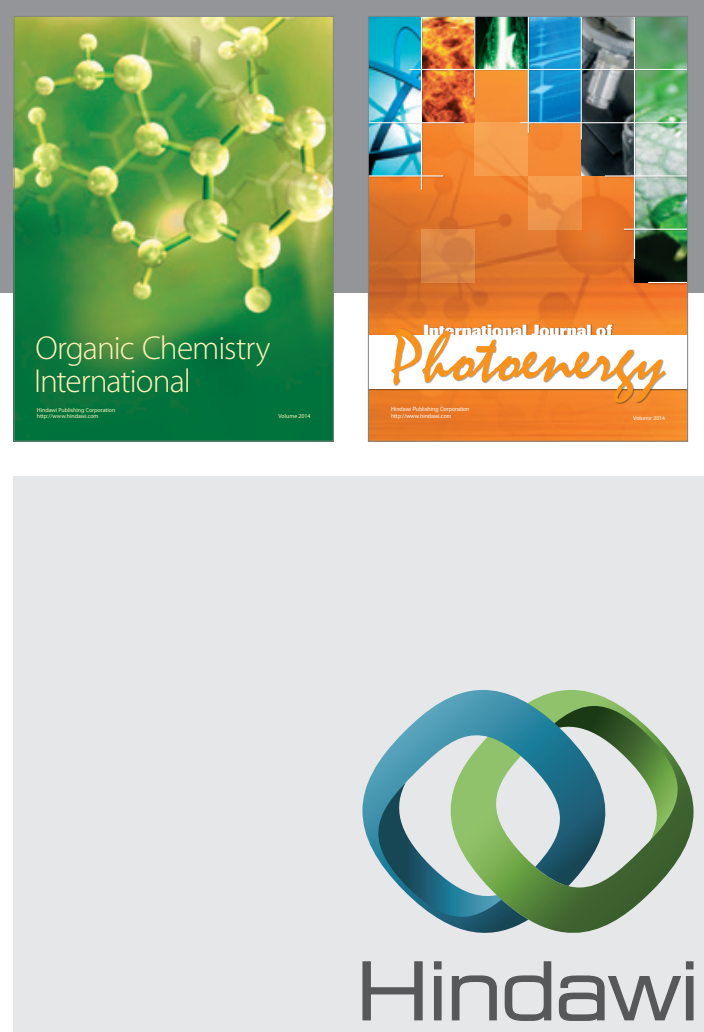

Submit your manuscripts at

http://www.hindawi.com

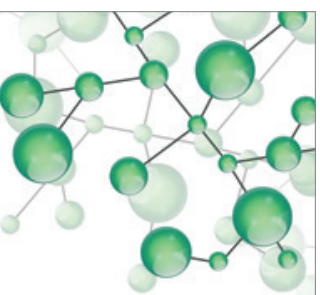

International Journal of

Inorganic Chemistry

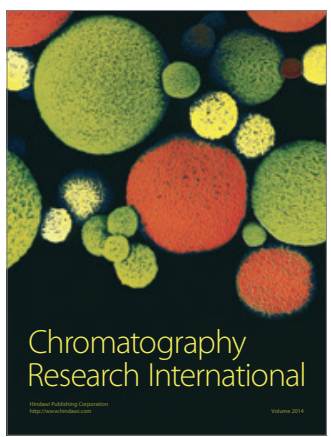

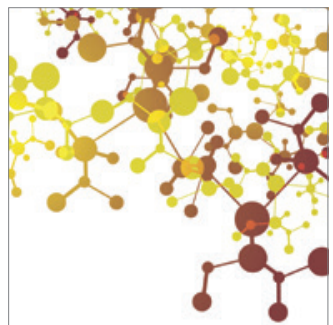

Applied Chemistry
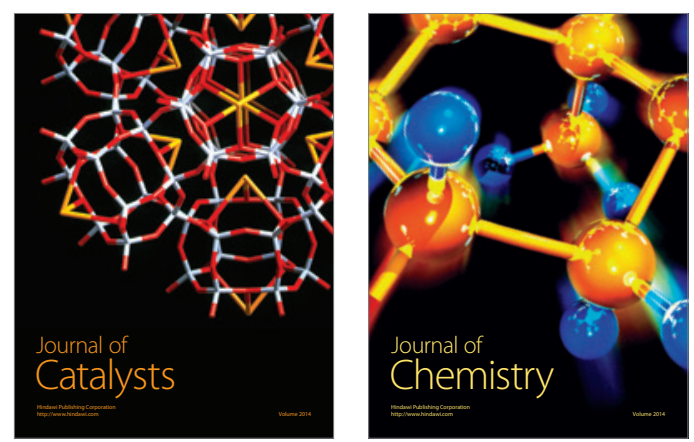
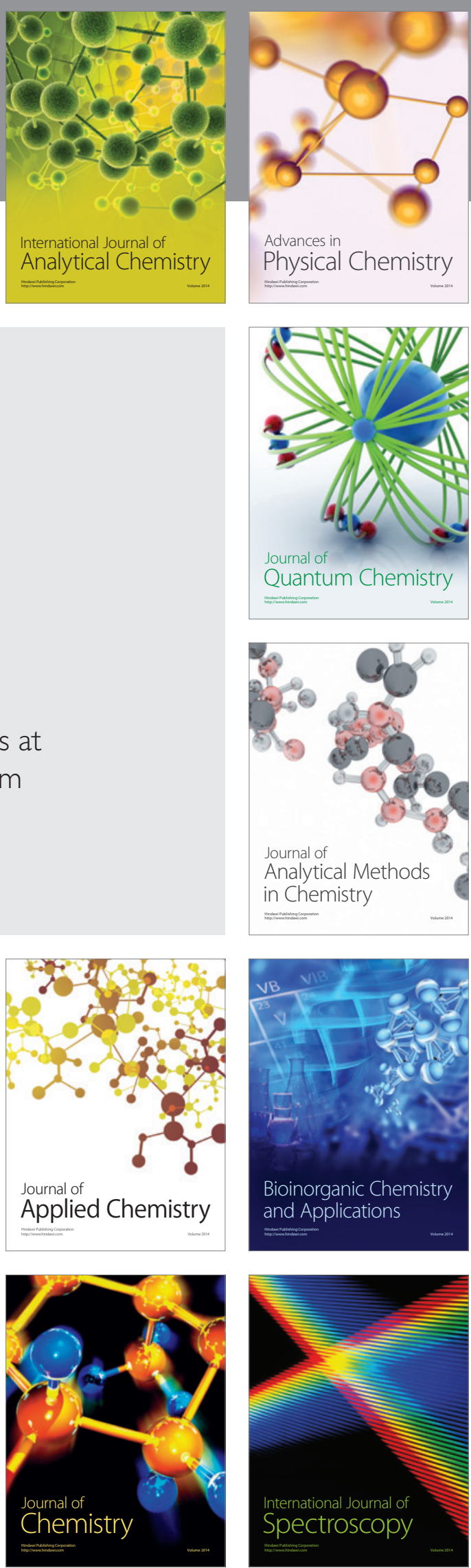